\title{
Effect of soil-applied calcium carbide and plant derivatives on nitrification inhibition and plant growth promotion
}

\author{
M. Kaleem Abbasi • M. Manzoor
}

Received: 29 July 2011/Revised: 8 February 2012/ Accepted: 3 August 2012/Published online: 29 March 2013

(C) Islamic Azad University (IAU) 2013

\begin{abstract}
The aim of this study was to evaluate the relative performance of three nitrification inhibitors (NIs) viz. calcium carbide $\left(\mathrm{CaC}_{2}\right)$, and plant derivatives of Pongamia glabra Vent. (karanj) and Melia azedarach (dharek) in regulating $\mathrm{N}$ transformations, inhibiting nitrification and improving $\mathrm{N}$ recovery in soil-plant systems. In the first experiment under laboratory incubation, soil was amended with $\mathrm{N}$ fertilizer diammonium phosphate $\left[\left(\mathrm{NH}_{4}\right)_{2} \mathrm{HPO}_{4}\right]$ at a rate of $200 \mathrm{mg} \mathrm{N} \mathrm{kg}^{-1}, \mathrm{~N}+\mathrm{CaC}_{2}, \mathrm{~N}+$ karanjin, and $\mathrm{N}+$ M. azedarach and incubated at $22{ }^{\circ} \mathrm{C}$ for 56 days period. Changes in total mineral $\mathrm{N}(\mathrm{TMN}), \mathrm{NH}_{4}{ }^{+}-\mathrm{N}$ and $\mathrm{NO}_{3}{ }^{-}-\mathrm{N}$ were examined during the study. A second experiment was conducted in a glasshouse using pots to evaluate the response of wheat to these amendments. Results indicated that more than $92 \%$ of the $\mathrm{NH}_{4}{ }^{+}$initially present had disappeared from the mineral $\mathrm{N}$ pool by the end of incubation. Application of NIs i.e., $\mathrm{CaC}_{2}$, karanjin, and $M$. azedarach resulted in a significant reduction in the extent of $\mathrm{NH}_{4}^{+}$disappearance by 49, 32, and $13 \%$, respectively. Accumulation of $\mathrm{NO}_{3}{ }^{-}-\mathrm{N}$ was much higher in $\mathrm{N}$ amended soil $57 \%$ compared to $11 \%$ in $\mathrm{N}+\mathrm{CaC}_{2}$, $13 \%$ in $\mathrm{N}+$ karanjin, and $18 \%$ in $\mathrm{N}+$ M. azedarach. Application of NIs significantly increased growth, yield, and $\mathrm{N}$ uptake of wheat. The apparent $\mathrm{N}$ recovery in $\mathrm{N}$-treated plants was $20 \%$ that was significantly increased to 38,34 , and $37 \%$ with $\mathrm{N}+\mathrm{CaC}_{2}, \mathrm{~N}+$ karanjin, and $\mathrm{N}+M$. azedarach, respectively. Among the three NIs tested, $\mathrm{CaC}_{2}$ and karanjin proved highly effective in
\end{abstract}

M. Kaleem Abbasi $(\bowtie) \cdot$ M. Manzoor Department of Soil and Environmental Sciences, Faculty of Agriculture, The University of Poonch, Rawalakot Azad Jammu and Kashmir, Pakistan e-mail: kaleemabbasi@yahoo.com inhibiting nitrification and retaining $\mathrm{NH}_{4}{ }^{+}-\mathrm{N}$ in the mineral pool for a longer period.

Keywords Nitrification - Nitrification inhibitor $\cdot \mathrm{N}$ recovery $\cdot \mathrm{NH}_{4}{ }^{+}$retention $\cdot \mathrm{NO}_{3}{ }^{-}$accumulation $\cdot \mathrm{N}$ losses

\section{Introduction}

Nitrogen is an essential nutrient controlling the diversity, dynamics, and functioning of many terrestrial, freshwater, and marine ecosystems. Agricultural ecosystems depend heavily on large inputs of $\mathrm{N}$ fertilizer to sustain productivity, as naturally fixed $\mathrm{N}$ is seldom adequate for highproduction systems (Dinnes et al. 2002; Subbarao et al. 2006a; Abbasi and Khizar 2012). However, N is a highly dynamic and mobile element and significant $\mathrm{N}$ losses occur as a result of $\mathrm{NO}_{3}{ }^{-}$leaching, denitrification, runoff, $\mathrm{NH}_{3}$ volatilization and gaseous emissions of $\mathrm{N}_{2} \mathrm{O}$, and $\mathrm{NO}$ to the atmosphere (Zaman et al. 2009). These losses of $\mathrm{N}$ have long-term adverse ecological and environmental effects contributing to eutrophication, loss of aquatic biodiversity, and increased $\mathrm{N}_{2} \mathrm{O}$ emissions (Warneke et al. 2011).

Most of the fertilizer $\mathrm{N}$ applied to soils (90\%) for agriculture production is in the form of ammonium $\left(\mathrm{NH}_{4}{ }^{+}\right.$), or $\mathrm{NH}_{4}{ }^{+}$-producing compounds. According to IFA report, world apparent ammonia consumption for the Year 2010 was about 121 million tonnes (IFA 2012). Much of this $\mathrm{NH}_{4}{ }^{+}$is usually oxidized quite rapidly to $\mathrm{NO}_{3}{ }^{-}$, a highly mobile form of $\mathrm{N}$, providing a much greater potential for $\mathrm{N}$ to be lostbeyond the rooting zone (leaching) and into the atmosphere as gaseous molecules $\left(\mathrm{N}_{2} \mathrm{O}, \mathrm{NO}\right.$, and $\mathrm{N}_{2}$ ) through denitrification (Subbarao et al. 2006a). It is estimated that nearly $70 \%$ of the applied $\mathrm{N}$ from managed ecosystems is lost through nitrification and 
subsequent processes (Raun and Johnson 1999; Glass 2003). These losses result in serious environmental consequences and inefficient use of both soil and applied $\mathrm{N}$ (Raun and Johnson 1999; Subbarao et al. 2006a).

Controlling the process of nitrification through inhibition or suppression of nitrifiers in soil is perhaps one of the most effective strategies to reduce $\mathrm{N}$ losses by $\mathrm{NO}_{3}{ }^{-}$ leaching and by gaseous $\mathrm{N}$ emissions that occur in nitrification (Rodgers 1986; Prasad and Power 1995; Subbarao et al. 2006b). Field evaluations suggested that if nitrification rates are reduced in agricultural systems, plants have more time to take up available $\mathrm{N}$, thereby improving $\mathrm{N}$ recovery and uptake and reducing $\mathrm{NO}_{3}{ }^{-}$leaching and associated off farm environmental impacts(Rodgers 1986; Subbarao et al. 2006b).

The losses of applied $\mathrm{N}$ associated with nitrification could be controlled or reduced by applying nitrification inhibitors (NIs). Rapid nitrification or oxidation of $\mathrm{NH}_{4}{ }^{+}$to $\mathrm{NO}_{3}{ }^{-}$in soil catalyzed by microbes had been found to be inhibited by NIs included nitrapyrin (2-chloro-6-tricholoro methyl pyridine), sodium azide, sodium chlorate, dicyandiamide (DCD), ATC (4-amino-1-2-4-triazole), N-serve, and certain other compounds (McCarty 1999; Abbasi et al. 2003; Fangueiro et al. 2009; Khalil et al. 2009; Zaman et al. 2009; Souri 2010; Pereira et al. 2010). The use of these synthetic NIs has been restricted to the academic experimental levels because of high cost, lack of availability, and adverse side effects (Patra and Sukhma 2009).

Apart from these chemically synthesized NIs, nitrification inhibitory properties of some inexpensive compounds like calcium carbide $\left(\mathrm{CaC}_{2}\right)$ and several plants materials like Karanji (Pongamia glabra), Neem (Azaddirachta indica), and tea (Camellia sinensis) waste have been evaluated by many researchers and their advantages and disadvantages have been reported (Freney et al. 2000, Kiran and Patra 2003; Majumdar 2002; Abbasi et al. 2011). Among these NIs, acetylene $\left(\mathrm{C}_{2} \mathrm{H}_{2}\right)$ has been shown to be a potent inhibitor of nitrification (Freney et al. 2000). However, $\mathrm{C}_{2} \mathrm{H}_{2}$ is a gas, therefore, it is difficult to apply and maintain at the required concentration in soil to inhibit the oxidation of ammonium. This problem can be overcome by coating calcium carbide with wax (as acetylene is a product of calcium carbide hydrolysis), or by forming a matrix with an insoluble material, to slow down its reaction with water, and produce acetylene in situ in soil (Freney et al. 1992; Smith et al. 1993; Freney et al. 2000).

The plant karanji is a source of furanoflavonoid "karanjin" which has been identified as having nitrification inhibitory properties. The nitrification inhibition by karanjin was observed to remain high for a period of approximately 6 weeks, with inhibition ranging between 9 and $76 \%$ for a range of soils studied (Majumdar et al. 2004). Similarly, fruits of dharek (Melia azedarach) are poisonous to humans and these are chemically related to Azadirachtin, the primary insecticidal compound in the commercially important neem oil. These compounds are probably antibacterial in action and display insecticidal properties; however, their effects on soil fertility and plant mineral uptake are not clear. In fact, a positive effects of fresh melia ground leaves on growth and mineral composition of plum hybrids during their acclimatization, was observed (Marino et al. 2009). Similarly, Toselli et al. (2010) recently reported that freshly ground melia derivatives did not inhibit nitrification in the soil but, rather, they stimulated mineral $\mathrm{N}$ release, $\mathrm{N}$ leaf concentration, root $\mathrm{N}$ uptake, and peach plant growth.

As compared to synthetic NIs, the natural NIs are ecofriendly, easily available, implying lower cost of production and can be included in the farming systems (Upadhyay et al. 2011). However, the use of these inhibitors for inhibiting nitrification, reducing $\mathrm{N}$ losses and increasing NUE in agriculture ecosystem is still not common. Keeping in view, this study was designated to evaluate the relative efficiency of karanjin (P. glabra Vent.), dharek (M. azedarach) (plant materials), and $\mathrm{CaC}_{2}$ (a chemical) to inhibit nitrification, improve $\mathrm{N}$ recovery in soil-plant system and enhance the growth and yield of wheat. This research has been carried out in the Department of Soil and Environmental Sciences, University of Azad Jammu and KashmirPakistan (Rawalakot), from November 2010 to May 2011.

\section{Materials and methods}

\section{Soil sampling/collection}

Soil was collected from an arable field located at the research farm, Faculty of Agriculture Rawalakot Azad Jammu and Kashmir. The study area lies between the altitude of 1,800-2,000 $\mathrm{m}$ above sea level and latitude $33-36^{\circ}$ in the north-east of Pakistan under the foothills of the great Himalayas at Rawalakot district, Poonch division, AJK, Pakistan. The soil in the study site was loam in texture, classified as a Humic Lithic Eutrudepts (Inceptosols). The field was barren at the time of sampling but previously maize and wheat were cultivated during the growing season. Soil samples were collected from the 0 to $15 \mathrm{~cm}$ depth at random from 5 different locations and mixed well. The field-moist soil was passed through a $4 \mathrm{~mm}$ sieve to eliminate coarse rock and plant material, thoroughly mixed to insure uniformity and stored at $4{ }^{\circ} \mathrm{C}$ prior to use. A sub-sample of about $500 \mathrm{~g}$ was taken, air dried and passed through $2 \mathrm{~mm}$ sieve and used for studying physical and chemical characteristics. The main physiochemical properties of the soil were determined on dry weight basis were: bulk density: $1.35 \mathrm{~g} \mathrm{~cm}^{-1}$ (intact soil 
core method); $\mathrm{pH}: 7.1$; total $\mathrm{C}: 4.81 \mathrm{~g} \mathrm{~kg}^{-1}$; total $\mathrm{N}$ : $0.89 \mathrm{~g} \mathrm{~kg}^{-1}$; total mineral $\mathrm{N}: 8.8 \mathrm{mg} \mathrm{kg}^{-1}$, available $\mathrm{P}$ : $7.6 \mathrm{mg} \mathrm{kg}^{-1}$ and available $\mathrm{K}: 87 \mathrm{mg} \mathrm{kg}^{-1}$.

\section{Laboratory incubation}

Field-moist soil samples were placed into polyethylene bags and pre-incubated at $22{ }^{\circ} \mathrm{C}$ to stabilize the microbial activity. Ten days after pre-incubation, $30 \mathrm{~g}$ of soil was weighed and transferred into glass jars of about $100 \mathrm{~mL}$ capacity. The initial moisture content of soil was adjusted to a water-filled pore space (WFPS) of approximately $58 \%$ that was maintained throughout the incubation. WFPS was calculated as follows: WFPS $=$ (soil gravimetric water content $\mathrm{X}$ bulk density)/[1- (bulk density/particle density)].

There were four $\mathrm{N}$ treatments with and without NIs i.e., $\mathrm{N}$ without $\mathrm{NIs} ; \mathrm{N}+\mathrm{CaC}_{2}, \mathrm{~N}+$ karanjin and $\mathrm{N}+M$. azedarach and a control (no N); eight sampling times: 0,7 , $14,21,28,35,42$, and 56 days and three replicates. Altogether, a total of 120 experimental units were used at the start of the experiment. An aqueous solution of diammonium phosphate $\left[\left(\mathrm{NH}_{4}\right)_{2} \mathrm{HPO}_{4}\right]$ i.e., DAP was applied as the $\mathrm{N}$ source to all pots except control to supply $200 \mathrm{mg} \mathrm{N} \mathrm{kg}^{-1}$ soil. A basal dose of $90 \mathrm{mg} \mathrm{P}_{2} \mathrm{O}_{5} \mathrm{~kg}^{-1}$ soil as single super phosphate (SSP) and $60 \mathrm{mg} \mathrm{K}_{2} \mathrm{O} \mathrm{kg}^{-1}$ soil as potassium sulfate was well mixed into the soil.

For the treatments subjected to inhibitors, $\mathrm{CaC}_{2}$ was obtained in powder form from Marij Scientific Traders, Rawalpindi Pakistan. Seeds/fruits of karanja (P. glabra Vent.) and $M$. azedarach were collected locally. Seeds were crushed and seed powder (500 g) was defatted by boiling in hexane $(2 \mathrm{~L})$ in a soxhlet apparatus for $24 \mathrm{~h}$. Karanjin and dharek (M. azedarach) was precipitated out on cooling the hexane extract in a refrigerator. After $72 \mathrm{~h}$, the precipitate was collected and crystallized in ethanol and its melting point was observed. It was re-crystallized a number of times in ethanol to yield the final product (Majumdar et al. 2004). A solution of karanjin and dharek was prepared by dissolving crystals of karanjin and $M$. azedarach in acetone, and the solution was added to the soil containing DAP (200 mg kg $\mathrm{m}^{-1}$ soil) at the rate of $20 \%$ of applied N (Majumdar et al. 2004).

The soil was homogeneously mixed with the respective amendments in $100 \mathrm{ml}$ glass pots. The mass of each pot was recorded. Pots were covered with parafilm with 3-4 small holes on the top to allow $\mathrm{O}_{2}$ exchange. Pots were incubated in an incubator at $22{ }^{\circ} \mathrm{C}$ and arranged in a completely randomized design. Soil moisture was checked/ adjusted after every 2 days by weighing the pots and adding the required amount of distilled water when the loss was greater than $0.05 \mathrm{~g}$. During this process, care was taken not to disturb the soil either through stirring or shaking.
Soil extraction and analysis

Samples of all the treatments incubated at different timings were analyzed for total mineral nitrogen (TMN) and ammonium-N $\left(\mathrm{NH}_{4}{ }^{+}-\mathrm{N}\right)$. Initial concentrations of TMN and $\mathrm{NH}_{4}{ }^{+}-\mathrm{N}$ at day 0 were determined by extracting soil samples with $200 \mathrm{ml}$ of $1 \mathrm{M} \mathrm{KCl}$ added directly to the flask immediately after adding each amendment. Thereafter, triplicate samples from each treatment were removed randomly from the incubator at different incubation periods and extracted by shaking for $1 \mathrm{~h}$ with $200 \mathrm{ml}$ of $1 \mathrm{M} \mathrm{KCl}$ followed by filtration through Whatman's No. 40 filter paper.

The mineral $\mathrm{N}$ contents of the extract were determined with steam distillation and the titration method (Keeney and Nelson 1982) using microkjeldahl's distillation apparatus prepared locally. Aliquots $(40 \mathrm{ml})$ of the extracts were pippetted into a distillation flask and steam distillation was carried out after adding $\mathrm{MgO}$ for $\mathrm{NH}_{4}{ }^{+}-\mathrm{N}$ determinations while for the determination of TMN, magnesium oxide $(\mathrm{MgO})+$ Deverda's alloy was added. Distillates were collected in $5 \mathrm{ml}$ of boric acid containing bromocresol green/methyl red mixed indicator and titrated against $0.05 \mathrm{M} \mathrm{HCl}$. Nitrate-N was calculated by subtracting $\mathrm{NH}_{4}{ }^{+}-\mathrm{N}$ from TMN. Any $\mathrm{NO}_{2}$ present would have been included in the $\mathrm{NO}_{3}{ }^{-}$fraction.

The inhibition of nitrification by NIs was calculated as reported by Sahrawat (1996) and Majumdar et al. (2001):

Inhibition of nitrification $(\%)=\frac{\mathrm{N}_{\mathrm{N}}-\mathrm{N}_{\mathrm{I}}}{\mathrm{N}_{\mathrm{N}}} \times 100$

where $\mathrm{N}_{\mathrm{N}}=$ nitrified $\mathrm{N}$, i.e., $\mathrm{NO}_{3}{ }^{-}-\mathrm{N}$ as percent of total mineral $\mathrm{N}$, i.e., $\left(\mathrm{NH}_{4}{ }^{+}-\mathrm{N}+\mathrm{NO}_{3}{ }^{-}-\mathrm{N}\right)$ in soil amended with $\mathrm{N}$ alone; $\mathrm{N}_{\mathrm{I}}=$ nitrified $\mathrm{N}$, i.e., $\mathrm{NO}_{3}{ }^{-}-\mathrm{N}$ as percent of total mineral $\mathrm{N}$, i.e., $\left(\mathrm{NH}_{4}{ }^{+}-\mathrm{N}+\mathrm{NO}_{3}{ }^{-}-\mathrm{N}\right)$ in soil amended with $\mathrm{N}$ combined with an inhibitor.

Nitrified N (\%) was calculated at different stages of the incubation according to Majumdar et al. (2001):

$$
\begin{aligned}
\text { Nitrified } \mathrm{N}(\%)= & \frac{\mathrm{NO}_{3}^{-}-\mathrm{N}}{\text { Total mineral } \mathrm{N}\left(\mathrm{NH}_{4}^{+}-\mathrm{N}+\mathrm{NO}_{3}^{-}-\mathrm{N}\right)} \\
& \times 100
\end{aligned}
$$

To calculate nitrified $\mathrm{N}$ by the above formula, initial soil $\mathrm{NO}_{3}{ }^{-}-\mathrm{N}$ and total mineral $\mathrm{N}$ at day 0 and the concentration in the control were subtracted from their respective content.

\section{Wheat growth and N-uptake}

A separate experiment was conducted in pots in the greenhouse at the Faculty of Agriculture, Rawalakot Azad Jammu and Kashmir. Wheat (Triticum aestivum L.) variety 
"Inqalab-91" was used as a test crop. Thoroughly cleaned earthen pots of $38 \mathrm{~cm}$ height and $18 \mathrm{~cm}$ width were used in the experiment. The same soil used in the laboratory incubation experiment was also used in this experiment after sieving to $<4 \mathrm{~mm}$. Each pot contained approximately $12 \mathrm{~kg}$ soil. There were six $\mathrm{N}$ treatments with and without NIs and a control, with three replicates, comprising 21 pots in total. The treatments included: $\mathrm{T}_{1}=$ control $\mathrm{T}_{2}=\mathrm{N}$ alone; $\mathrm{T}_{3}=\mathrm{N}+\mathrm{CaC}_{2}$ at the rate $15 \mathrm{mg} \mathrm{kg}{ }^{-1} ; \mathrm{T}_{4}=\mathrm{N}+$ $\mathrm{CaC}_{2}$ at the rate $30 \mathrm{mg} \mathrm{kg}{ }^{-1} ; \mathrm{T}_{5}=\mathrm{N}+\mathrm{CaC}_{2}$ at the rate $45 \mathrm{mg} \mathrm{kg}^{-1} ; \mathrm{T}_{6}=\mathrm{N}+$ karanjin, and $\mathrm{T}_{7}=\mathrm{N}+M$. azedarach. An aqueous solution of diammonium phosphate $\left[\left(\mathrm{NH}_{4}\right)_{2} \mathrm{HPO}_{4}\right]$ i.e., DAP was applied as $\mathrm{N}$ source to all pots except control to supply $200 \mathrm{mg} \mathrm{N} \mathrm{kg}^{-1}$ soil. A $200 \mathrm{mg}^{-1}$ solution of karanjin and $M$. azedarach was prepared by dissolving crystals of karanjin and dharek in acetone and the solution was added to the soil containing DAP (200 mg kg $\mathrm{mg}^{-1}$ soil) at the rate of $20 \%$ of applied $\mathrm{N}$

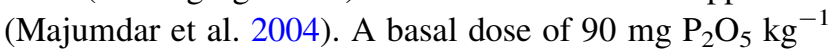
soil as SSP and $60 \mathrm{mg} \mathrm{K}_{2} \mathrm{O} \mathrm{kg}^{-1}$ soil as potassium sulfate was well mixed into the soil before sowing. The pots were arranged in a completely randomized design.

The soil was moistened with water and maintained at $58 \%$ water-filled pore space. In each pot, eight seeds were sown at a depth of about $4 \mathrm{~cm}$ on November 06, 2010. Pots were kept under shade to reduce evapo-transpiration during the course of germination. After complete germination, plants were thinned to six plants per pot. All pots were equally irrigated when needed. Two plants from each treatment were sampled at Vn, milking and maturity stages. At each sampling time data were collected for shoot length, root length, shoot dry weight, and root dry weight. At maturity, number of grains per spike, 1000 -grain weight and grain yield per plant was also recorded. Bulked plant parts (shoot + leave) were washed, and cleaned. The cleaned plant parts and grains were oven dried at $70{ }^{\circ} \mathrm{C}$ for $48 \mathrm{~h}$. For analysis of the $\mathrm{N}$ content in grain and straw, oven-dried plant material (grain and straw) from each plot were ground separately with a grinder (Polymix PX-MFC 90D; Switzerland) to pass through a $2 \mathrm{~mm}$-mesh sieve. The $\mathrm{N}$ contents in samples were determined by the Kjeldahl method (Jackson 1962).

\section{Statistical analysis}

All data were statistically analyzed by multifactorial analysis of variance (ANOVA) using the software package Statgraphics (1992). Least significant differences (LSD) are given to indicate significant variations between the values of either treatments or time intervals. Confidence values $(P)$ are given in the text for the significance between treatments, manures, time interval and their interactions. A probability level of $\leq 0.05$ was considered significant.

\section{Results and discussion}

\section{Changes in $\mathrm{NH}_{4}{ }^{+}-\mathrm{N}$}

The $\mathrm{NH}_{4}{ }^{+}-\mathrm{N}$ concentration in the un-amended control was quite low $\left(<11 \mathrm{mg} \mathrm{kg}^{-1}\right)$ at the start (day 0$)$, continued to decrease with time and was negligible by the end of incubation (day 56) (Fig. 1). The low $\mathrm{N}$ concentration in
Fig. 1 Changes in the concentration of $\mathrm{NH}_{4}^{+}-\mathrm{N}$ and accumulation of $\mathrm{NO}_{3}{ }^{-}-\mathrm{N}$ in a soil collected from an arable filed, amended with fertilizer $\mathrm{N}$ with and without nitrification inhibitors and incubated at $22{ }^{\circ} \mathrm{C}$ under controlled laboratory conditions. The legends indicate: $\mathrm{T}_{1}=$ control; $\mathrm{T}_{2}=\mathrm{N}$ without nitrification inhibitors (NIs);

$\mathrm{T}_{3}=\mathrm{N}+\mathrm{CaC}_{2}$;

$\mathrm{T}_{4}=\mathrm{N}+$ karanjin;

$\mathrm{T}_{5}=\mathrm{N}+$ M. azedarach
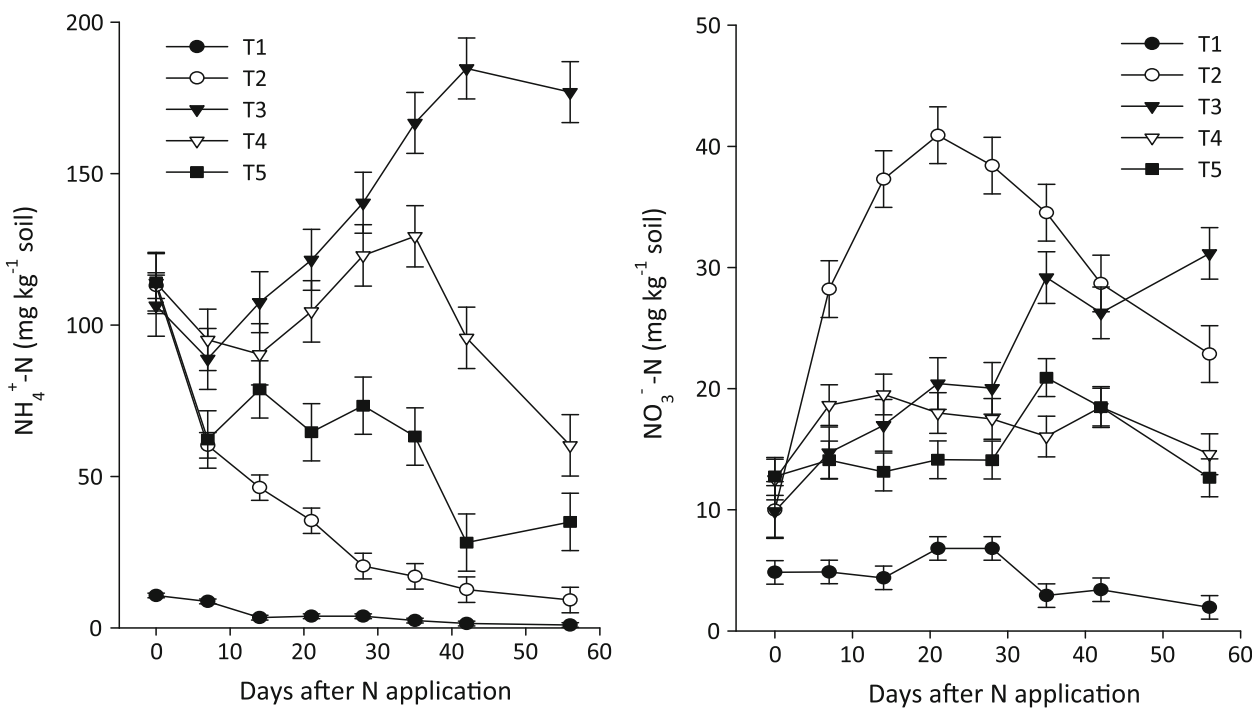
the control soil throughout the incubation indicated low mineralization which was unusual because the soil collected from an arable field cultivated for crop production. These results were in contrast to our previous study, where the available $\mathrm{N}$ of an arable control soil was $39 \mathrm{mg} \mathrm{kg}^{-1}$ during a 50 day incubation (Abbasi et al. 2011).

The $\mathrm{NH}_{4}{ }^{+}-\mathrm{N}$ concentration of $\mathrm{N}$ treated soils (with and without NIs) was between 97 and $110 \mathrm{mg} \mathrm{N} \mathrm{kg}^{-1}$ at day 0 , with the difference between the $\mathrm{N}$ treatments being nonsignificant (Fig. 1). Despite adding $200 \mathrm{mg} \mathrm{NH}_{4}^{+}-\mathrm{N}$ per $\mathrm{kg}$ soil, only about $106 \mathrm{mg}$ (mean) of the added $\mathrm{N}$ was recovered as $\mathrm{NH}_{4}{ }^{+}-\mathrm{N}$ just after $\mathrm{N}$ application (day 0). Under similar experimental conditions, Souri (2008) also reported less $\mathrm{NH}_{4}{ }^{+}-\mathrm{N}$ recovery than the applied $\mathrm{N}$ and explained that the $\mathrm{N}$ unaccounted for may be due to $\mathrm{NH}_{4}{ }^{+}$ fixation by clay minerals, volatilization as $\mathrm{NH}_{3}$, or inefficient extraction of $\mathrm{NH}_{4}{ }^{+}$, which has been done with $1 \mathrm{M}$ $\mathrm{KCl}$. The concentration of $\mathrm{KCl}$ used for extraction was $1 \mathrm{M}$ that might be a major factor for inefficient extraction of $\mathrm{NH}_{4}^{+}$.

In the soil to which $\mathrm{N}$ was added (without NIs), initial $\mathrm{NH}_{4}{ }^{+}$concentration significantly $(P \leq 0.05)$ decreased with time and very little $\mathrm{NH}_{4}{ }^{+}$was left in the mineral $\mathrm{N}$ pool by the end of incubation $\left(9.2 \mathrm{mg} \mathrm{kg}^{-1}\right.$ soil) (Fig. 1). Results showed that $96 \%$ of the applied $\mathrm{N}$ had disappeared over a period of 56 days. During this $\mathrm{NH}_{4}{ }^{+}$disappearance, concentrations of $\mathrm{NO}_{3}{ }^{-}-\mathrm{N}$ increased to a maximum of $41 \mathrm{mg}$ of $\mathrm{NO}_{3}{ }^{-}-\mathrm{N} \mathrm{kg}^{-1}$ at day 21 (Fig. 1), indicating that nitrification was also occurring. However, the buildup of $\mathrm{NO}_{3}-\mathrm{N}$ was lower than the rate of $\mathrm{NH}_{4}{ }^{+}$depletion. The pattern of changes in $\mathrm{NH}_{4}{ }^{+}-\mathrm{N}$ and $\mathrm{NO}_{3}{ }^{-}-\mathrm{N}$ observed here was almost similar to that observed in our previous study where more than $58 \%$ of applied $\mathrm{N}$ had been disappeared over a period of 50 days and only $21 \%$ of depleted $\mathrm{N}$ was accumulated as $\mathrm{NO}_{3}{ }^{-}-\mathrm{N}$ (Abbasi et al. 2011). We had earlier concluded that under the experimental conditions reported here nitrification-denitrification occurred simultaneously (Abbasi and Adams 2000a, b). Produced $\mathrm{NO}_{3}{ }^{-}$ can simply be diffused into adjacent microsites of denitrification, therefore, a substantial accumulation of $\mathrm{NO}_{3}-\mathrm{N}$ would not be expected where both nitrification and denitrification occur simultaneously (Abbasi and Adams 1998). Remde and Conrad (1991) reported that depletion of $\mathrm{NH}_{4}{ }^{+}$ in the soil was apparently not balanced by the production of $\mathrm{NO}_{2}$ and $\mathrm{NO}_{3}{ }^{-}$, and this discrepancy may be due to the simultaneous nitrification and denitrification. However, the soil incubated under aerobic conditions with moisture content of about $60 \%$ WFPS, denitrification may not be considered the only loss mechanism of $\mathrm{N}$ unaccounted for. Therefore, further investigations are suggested to explore the routes of $\mathrm{N}$ losses occurred even under controlled conditions without crop uptake and leaching loss.

A significant reduction in $\mathrm{NH}_{4}{ }^{+}-\mathrm{N}$ concentration was also observed in soils treated with NIs i.e., karanjin and $M$. azedarach but the rate and amount of $\mathrm{NH}_{4}{ }^{+}$depletion was slower than the soil treated with $\mathrm{N}$ (without NIs). For example, only about $9.2 \mathrm{mg} \mathrm{kg}^{-1}$ of $\mathrm{NH}_{4}^{+}$was left in the mineral $\mathrm{N}$ pool of $\mathrm{N}$ treated soil by the end of incubation, while 60.3 , and $35.0 \mathrm{mg} \mathrm{kg}^{-1}$ of $\mathrm{NH}_{4}{ }^{+}-\mathrm{N}$ was persisted and retained until the end in the soil treated with $\mathrm{N}+$ karanjin and $\mathrm{N}+$ M. azedarach, respectively (Fig. 2). The $\mathrm{NH}_{4}{ }^{+}-\mathrm{N}$ concentration in the treatment receiving $\mathrm{N}+$ karanjin showed temporary increase and decrease between days 14 and 42 . The reasons for the development of this trend are
Fig. 2 Over all changes (average over 56 days incubation) in $\mathrm{NH}_{4}^{+}-\mathrm{N}$ and accumulation/inhibition of $\mathrm{NO}_{3}{ }^{-}-\mathrm{N}$ in a soil collected from an arable filed, amended with fertilizer $\mathrm{N}$ with and without nitrification inhibitors and incubated at $22{ }^{\circ} \mathrm{C}$ under controlled laboratory conditions. The symbols on $X$-axis indicate: $\mathrm{T}_{1}=$ Control; $\mathrm{T}_{2}=\mathrm{N}$ without nitrification inhibitors (NIs);

$\mathrm{T}_{3}=\mathrm{N}+\mathrm{CaC}_{2}$;

$\mathrm{T}_{4}=\mathrm{N}+$ karanjin;

$\mathrm{T}_{5}=\mathrm{N}+$ M. azedarach
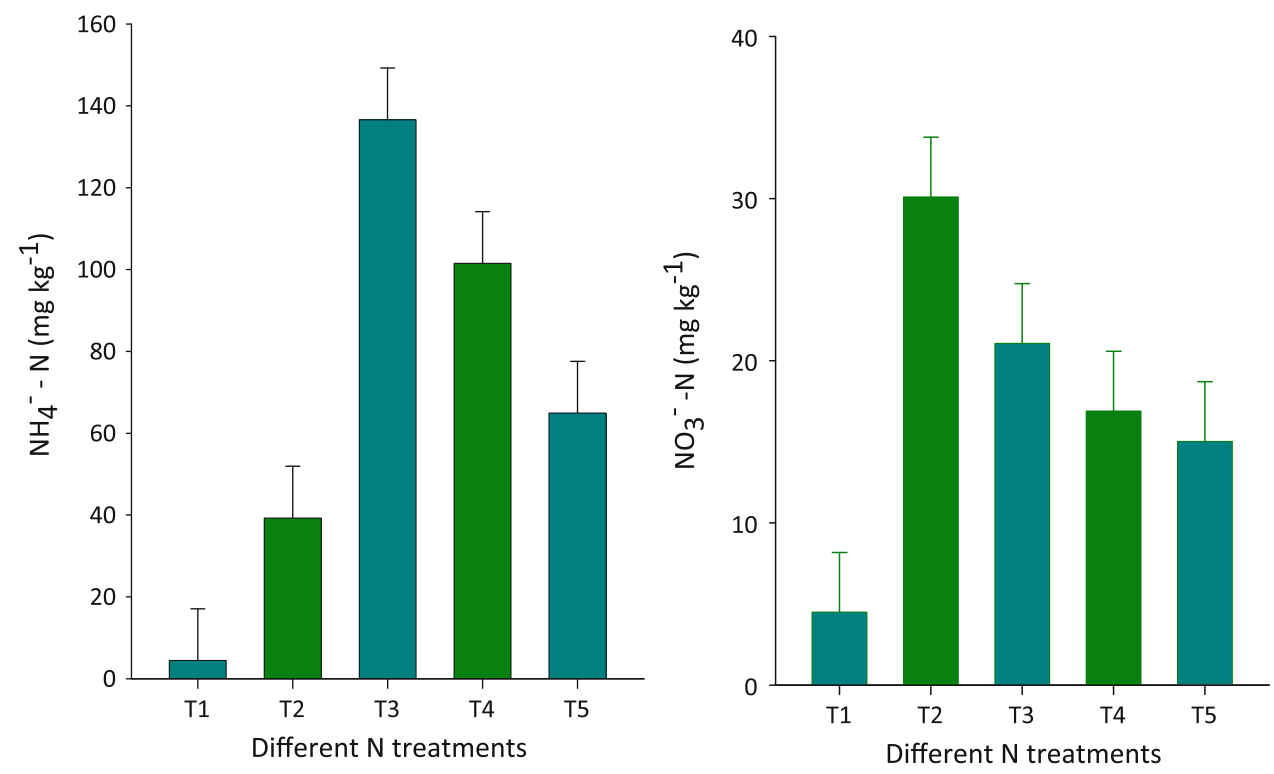
Table 1 Net rates of nitrification $\left(\mathrm{NO}_{3}{ }^{-}-\mathrm{N} \mathrm{mg} \mathrm{kg}{ }^{-1} \mathrm{day}^{-1}\right)$ in soil amended with $\mathrm{N}\left(200 \mathrm{mg} \mathrm{N} \mathrm{kg}^{-1}\right.$ soil) with and without nitrification inhibitors over 56 days of laboratory incubation

\begin{tabular}{|c|c|c|c|c|c|c|c|c|c|}
\hline \multirow[t]{3}{*}{ Treatments } & \multicolumn{9}{|c|}{$\mathrm{NO}_{3}{ }^{-}-\mathrm{N}\left(\mathrm{mg} \mathrm{kg}^{-1}\right.$ day $^{-1}$ soil $)$} \\
\hline & \multicolumn{9}{|c|}{ Days after $\mathrm{N}$ application } \\
\hline & 7 & 14 & 21 & 28 & 35 & & 42 & 56 & $\operatorname{LSD}(P \leq 0.05)$ \\
\hline $\mathrm{T}_{1}$ & 0.00 & -0.03 & 0.09 & 0.07 & -0.05 & & -0.03 & -0.05 & 0.01 \\
\hline $\mathrm{T}_{2}$ & 2.61 & 1.95 & 1.47 & 1.02 & 0.70 & & 0.45 & 0.23 & 0.23 \\
\hline $\mathrm{T}_{3}$ & 0.69 & 0.51 & 0.50 & 0.36 & 0.55 & & 0.39 & 0.38 & 0.14 \\
\hline $\mathrm{T}_{4}$ & 0.88 & 0.50 & 0.26 & 0.18 & 0.10 & & 0.14 & 0.04 & 0.09 \\
\hline $\mathrm{T}_{5}$ & 0.19 & 0.03 & 0.07 & 0.05 & 0.23 & & 0.14 & 0.00 & 0.06 \\
\hline $\operatorname{LSD}(P \leq 0.05)$ & 0.46 & 0.27 & 0.21 & 0.16 & 0.12 & & 0.13 & 0.13 & \\
\hline \multicolumn{10}{|c|}{ Treatments effect (average over $0-56$ days; $\mathrm{mg} \mathrm{kg}^{-1}$ soil) } \\
\hline $\mathrm{T}_{1}$ & $\mathrm{~T}_{2}$ & & 3 & & & & $\mathrm{~T}_{5}$ & & $\operatorname{LSD}(\mathrm{P} \leq 0.05)$ \\
\hline 0.00 & 1.20 & & .48 & & & & 0.10 & & 0.174 \\
\hline \multicolumn{10}{|c|}{ Timings effect (average over $\mathrm{T}_{1}-\mathrm{T}_{5} ; \mathrm{mg} \mathrm{kg}^{-1}$ soil) } \\
\hline 7 & & 21 & 28 & & & 42 & & 56 & $\operatorname{LSD}(P \leq 0.05)$ \\
\hline 0.87 & & 0.48 & 0.34 & & & 0.22 & & 0.12 & 0.116 \\
\hline
\end{tabular}

$\mathrm{T}_{1}$, control; $\mathrm{T}_{2}, \mathrm{~N}$ without nitrification inhibitors (NIs); $\mathrm{T}_{3}, \mathrm{~N}+\mathrm{CaC}_{2} ; \mathrm{T}_{4}, \mathrm{~N}+$ karanjin; $T_{5}, \mathrm{~N}+$ M. azedarach

not known. The response of $\mathrm{NH}_{4}{ }^{+}$turnover to soil with $\mathrm{N}+\mathrm{CaC}_{2}$ was quite different and except day 7 , concentration of $\mathrm{NH}_{4}{ }^{+}$was significantly increased throughout the incubation (Fig. 1). However, in response to the total $\mathrm{N}$ applied $\left(200 \mathrm{mg} \mathrm{kg}^{-1}\right.$ ), about $12 \%$ of $\mathrm{NH}_{4}{ }^{+}$had been unaccounted for by the end of incubation. These results indicated that $\mathrm{CaC}_{2}$ and karanjin were highly effective in retaining $\mathrm{NH}_{4}{ }^{+}-\mathrm{N}$ in mineral pool at higher concentration and for longer period. It appeared that addition of NIs inhibited nitrification and consequently denitrification by restricting the supply of $\mathrm{NO}_{3}{ }^{-}$to the denitrifying organisms (Souri 2010; Pereira et al. 2010; Abbasi et al. 2011), resulting in relatively higher concentration of $\mathrm{NH}_{4}{ }^{+}$in these treatments. However, it is likely to mention that under arable soil deficient in organic matter, denitrification and $\mathrm{N}_{2} \mathrm{O}$ may not be the sole cause of $\mathrm{NH}_{4}{ }^{+}$depletion. It is important to explore other possible loss routes of added $\mathrm{NH}_{4}{ }^{+}$in the soil.

Results indicated that instead of decreasing $\mathrm{NH}_{4}{ }^{+}$to the initial value recorded at day 0 , concentration of $\mathrm{NH}_{4}{ }^{+}$in $\mathrm{N}+\mathrm{CaC}_{2}$ treated soil was significantly increased over time (Fig. 1). The tendency of $\mathrm{NH}_{4}^{+}$turnover observed here was in accordance with the previous studies. For example, when $\mathrm{CaC}_{2}$ was applied with urea $\mathrm{N}$, the $\mathrm{NH}_{4}{ }^{+}$ concentration in soil remained at high level for 36 days and increased from $30 \mathrm{mg} \mathrm{kg}^{-1}$ to about $38 \mathrm{mg} \mathrm{kg}^{-1}$ (Keerthisinghe et al. 1993). Similarly, in another experiment the concentration of $\mathrm{NH}_{4}{ }^{+}$was increased by 27 and $34 \%$ when $\mathrm{CaC}_{2}$ was applied to urea $\mathrm{N}$ (Keerthisinghe et al. 1996). However, the mechanism involved in $\mathrm{CaC}_{2}$ action in increasing $\mathrm{NH}_{4}{ }^{+}$level is not understood. It may possible that $\mathrm{CaC}_{2}$ application to a soil resulted in the priming of mineralization of residual soil organic matter.

Accumulation of $\mathrm{NO}_{3}{ }^{-}-\mathrm{N}$

The concentration of $\mathrm{NO}_{3}{ }^{-}-\mathrm{N}$ in the control without $\mathrm{N}$ was low $\left(<5 \mathrm{mg} \mathrm{kg}^{-1}\right)$, remained consistent till day 42 and thereafter further decreased (Fig. 1). The $\mathrm{NO}_{3}{ }^{-}-\mathrm{N}$ in $\mathrm{N}$ amended soil (without NIs) increased $(P \leq 0.05)$ during incubation to a maximum concentration of $40.9 \mathrm{mg} \mathrm{kg}^{-1}$ on day 21 . The concentration remained stable until day 35 and thereafter significantly decreased to a minimum of $23 \mathrm{mg} \mathrm{kg}^{-1}$ by the end of the 56 days. The extent and rate of $\mathrm{NO}_{3}{ }^{-}-\mathrm{N}$ accumulation in NIs treated soils was much lower compared to $\mathrm{N}$ treated soil (without NIs). For example, the concentrations of $\mathrm{NO}_{3}{ }^{-}-\mathrm{N}$ in $\mathrm{N}+\mathrm{CaC}_{2}$, $\mathrm{N}+$ karanjin and $\mathrm{N}+M$. azedarach ranged between 15 and 31,15 and 20 and 13 and $21 \mathrm{mg} \mathrm{kg}^{-1}$, respectively compared to the 23 and $41 \mathrm{mg} \mathrm{kg}^{-1}$ in $\mathrm{N}$ treated soil 


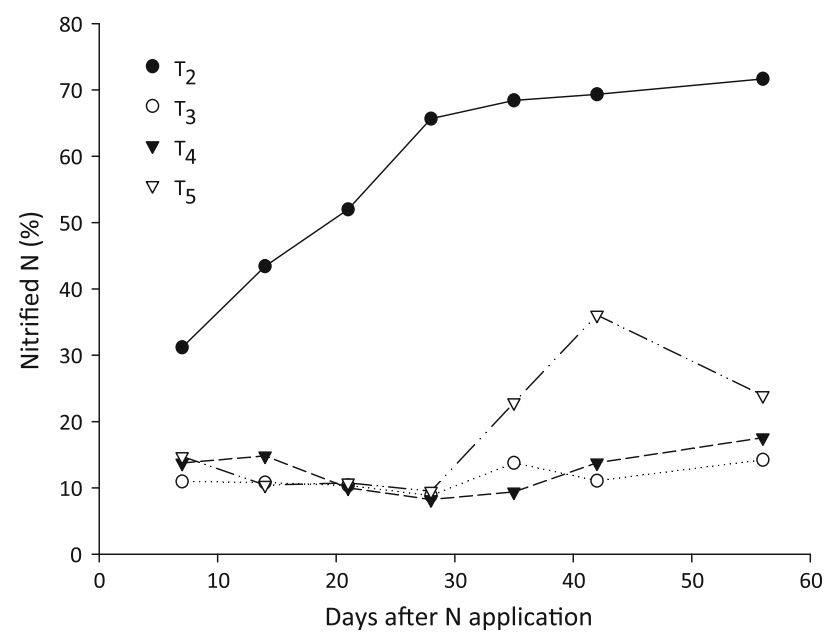

Fig. 3 The amount of $\mathrm{NO}_{3}{ }^{-}-\mathrm{N}$ nitrified (\%) as percent of total mineral $\mathrm{N}$ affected by NIs during 56 days incubation. The legends indicate: $T_{1}=$ Control; $T_{2}=\mathrm{N}$ without nitrification inhibitors (NIs); $T_{3}=\mathrm{N}+\mathrm{CaC}_{2} ; T_{4}=\mathrm{N}+$ karanjin; $T_{5}=\mathrm{N}+$ M. azedarach

without NIs. Averaged across different timings, accumulation of $\mathrm{NO}_{3}{ }^{-}$in the treatments receiving $\mathrm{N}, \mathrm{N}+\mathrm{CaC}_{2}$, $\mathrm{N}+$ karanjin and $\mathrm{N}+$ M. azedarac was 30, 21, 17, and $15 \mathrm{mg} \mathrm{kg}^{-1}$, respectively (Fig. 2). These values indicated that NIs included $\mathrm{CaC}_{2}$, karanjin and $M$. azedarach were able to inhibit nitrification by 69,67 , and $57 \%$, respectively.

Net rates of nitrification showed a similar trend to that observed for $\mathrm{NO}_{3}{ }^{-}-\mathrm{N}$ accumulation. Net rates of nitrification for $\mathrm{N}$ amended soil without NIs were significantly higher $(P \leq 0.05)$ than the rates recorded for soils with NIs (Table 1). Comparative analysis indicated that net rates of nitrification for $\mathrm{N}$ amended soil (without NIs) ranged between 1.02 and $2.61 \mathrm{mg} \mathrm{kg}^{-1}$ day $^{-1}$ between 7 and 28 day with a maximum rate in the initial stage of incubation (day 7). Thereafter, rates declined to a minimum of $0.23 \mathrm{mg} \mathrm{kg}^{-1}$ day ${ }^{-1}$ on day 56 . In contrast, net rates of nitrification in soil with NIs were much lower and the highest rates of $0.88 \mathrm{mg} \mathrm{kg}^{-1}$ day ${ }^{-1}$ recorded on day 7 for the $\mathrm{N}+$ karanjin treatment. The average net rates of nitrification in soil with $\mathrm{N}, \mathrm{N}+\mathrm{CaC}_{2}, \mathrm{~N}+$ karanjin and $\mathrm{N}+$ M. azedarach were $1.20,0.48,0.30$ and $0.10 \mathrm{mg} \mathrm{kg}^{-1}$ day $^{-1}$, respectively showing a substantial inhibition of nitrification by NIs.

The extent of nitrified $\mathrm{N}\left(\mathrm{NO}_{3}{ }^{-}-\mathrm{N}\right)$ as percent of total mineral $\mathrm{N}\left[\mathrm{NH}_{4}{ }^{+}-\mathrm{N}+\mathrm{NO}_{3}{ }^{-}-\mathrm{N}\right]$ was much higher in $\mathrm{N}$ treated soil without NIs (average $57 \%$ ) compared to $\mathrm{N}+\mathrm{CaC}_{2}(11 \%), \mathrm{N}+$ karanjin $(13 \%)$ and $\mathrm{N}+$ M. azedarach (18\%) (Fig. 3), confirmed the inhibitory effects of tested NIs on nitrification. Percent inhibition of nitrification was calculated to find out the effectiveness of three inhibitors used in the study. The percent inhibition of nitrification by $\mathrm{CaC}_{2}$, karanjin and M. azedarach ranged between 69,67 , and $57 \%$, respectively indicating $\mathrm{CaC}_{2}$ and karanjin were superior to $M$. azedarach.

Several previous studies clearly indicated nitrification inhibitory properties of $\mathrm{CaC}_{2}$ (Freney et al. 1992; Freney et al. 2000; Keerthisinghe et al. 1993, 1996). The inhibitory effect of $\mathrm{CaC}_{2}$ is attributed to its capacity to release acetylene which is considered a potent nitrification inhibitor (Smith et al. 1993). The effect of karanjin reported here is in accordance with that reported earlier by Majumdar (2002) under laboratory conditions where karanjin inhibited nitrification by $62-75 \%$ and mitigated $\mathrm{N}_{2} \mathrm{O}$ emission by $92-96 \%$. In another experiment conducted under laboratory incubation, nitrification inhibition by karanjin ranged between 9 and $76 \%$, remained high for a period of approximately 6 weeks and decreased with time (Majumdar et al. 2004). Similarly, in this study, the plant product M. azedarach inhibited nitrification by $57 \%$. However, the potential of $M$. azedarach to retain $\mathrm{NH}_{4}{ }^{+}$in mineral $\mathrm{N}$ pool and its persistence to inhibit nitrification for longer period was lower when compared with $\mathrm{CaC}_{2}$ and karanjin. In contrast to our findings, Toselli et al. (2010) reported that M. azedarach did not inhibit soil $\mathrm{NO}_{3}{ }^{-}-\mathrm{N}$, rather stimulated the release of mineral $\mathrm{N}$.

Recovery of applied $\mathrm{N}$ in soil

Effects of NIs on changes in TMN indicated that applied $\mathrm{N}$ started to disappear shortly after application (Table 2). By the end of incubation, $70 \%$ of the applied $\mathrm{N}$ had been depleted from the mineral $\mathrm{N}$ pool. In the soils amended with NIs, the extent and rate of depletion was much lower and the loss of applied $\mathrm{N}$ from $\mathrm{N}+\mathrm{CaC}_{2}, \mathrm{~N}+$ karanjin and $\mathrm{N}+$ M. azedarach was 26, 45, and $64 \%$, respectively.

With regard to soil $\mathrm{N}$ recovery, $\mathrm{CaC}_{2}$ proved highly effective in increasing $\mathrm{N}$ recovery of applied $\mathrm{N}$ followed by karanjin while $M$. azedarach was found less effective (Table 3). When $\mathrm{N}$ was applied without NIs, the ANR was $30 \%$. Addition of the NIs $\mathrm{CaC}_{2}$, and karanjin substantially increased of $\mathrm{N}$ by 74 , and $55 \%$, respectively, while the ANR by $M$. azedarach was $36 \%$, close to that of the $\mathrm{N}$ only treatment. Thus, of the total amount of $\mathrm{N}$ applied, 6-44\% more N was recovered when NIs were added to the soil. Keerthisinghe et al. (1993) found $84 \%$ recovery of applied $\mathrm{N}$ from a $\mathrm{CaC}_{2}$ treatment compared with $43 \%$ for the nitrapyrin and control treatments. A $46 \%$ greater recovery of applied $\mathrm{N}$ was recorded in soil-plant system when $\mathrm{CaC}_{2}$ was applied to irrigated wheat (Freney et al. 1993). Apparent $\mathrm{N}$ recovery of soil amended with neem seedcake (a plant material) was $83 \%$ compared with $63 \%$ for soil amended with urea $\mathrm{N}$ without NIs (Abbasi et al. 2011). Kiran and Patra (2003) used essential oil bearing 
Table 2 Changes in the total mineral $\mathrm{N}\left(\mathrm{NH}_{4}{ }^{+}-\mathrm{N}+\mathrm{NO}_{3}{ }^{-} \mathrm{N}\right)$ in soil amended with $\mathrm{N}\left(200 \mathrm{mg} \mathrm{N} \mathrm{kg}{ }^{-1}\right.$ soil $)$ with and without nitrification inhibitors over 56 days of laboratory incubation

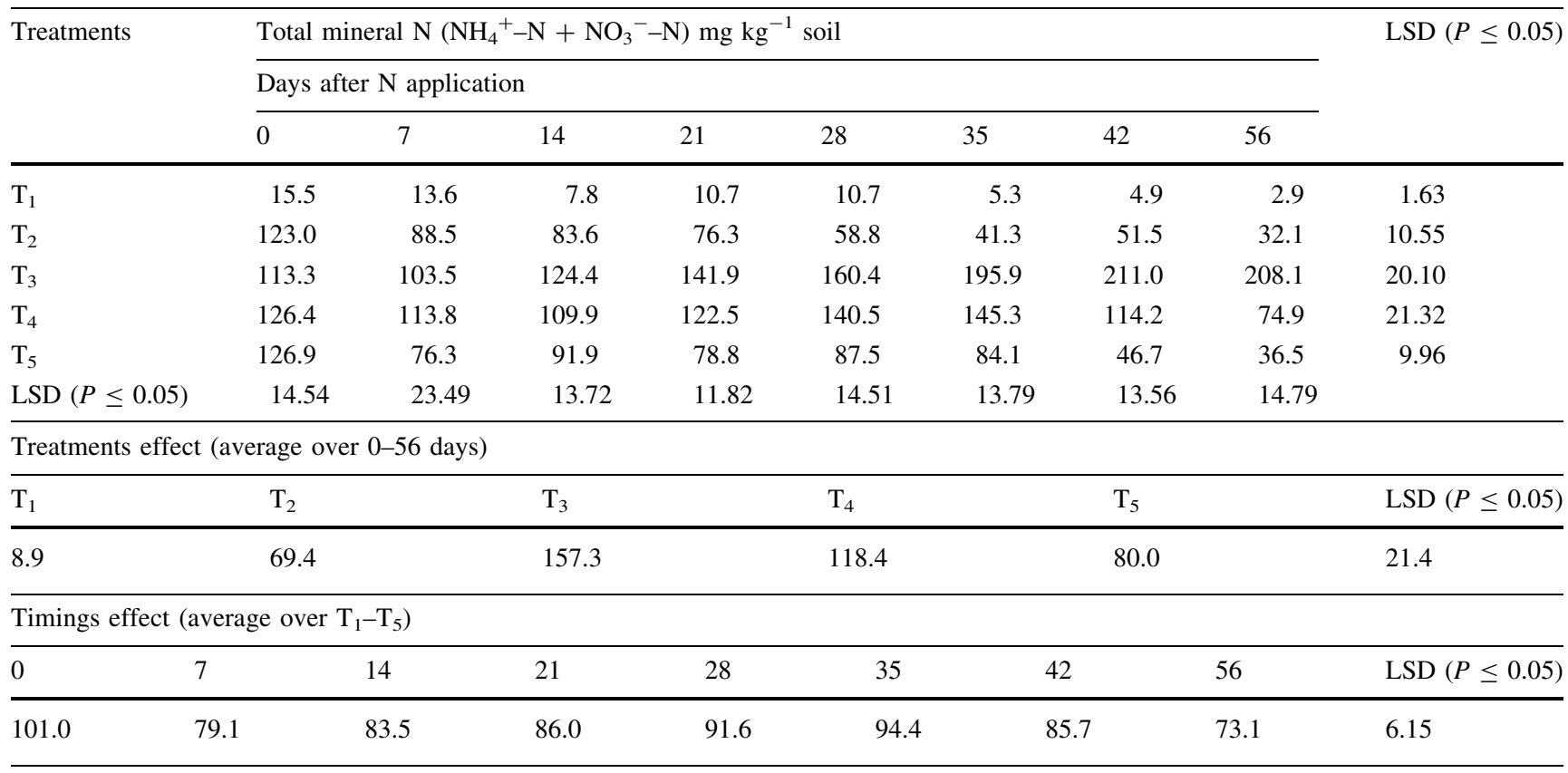

$\mathrm{T}_{1}$, control; $\mathrm{T}_{2}, \mathrm{~N}$ without nitrification inhibitors (NIs); $\mathrm{T}_{3}, \mathrm{~N}+\mathrm{CaC}_{2} ; \mathrm{T}_{4}, \mathrm{~N}+$ karanjin; $T_{5}, \mathrm{~N}+$ M. azedarach

Table 3 Fate and apparent recovery of $\mathrm{N}$ (at the rate of $200 \mathrm{mg} \mathrm{N} \mathrm{kg}^{-1}$ soil) applied to soil with and without nitrification inhibitors over 56 days of laboratory incubation

\begin{tabular}{lccccc}
\hline Treatments & $\begin{array}{l}\mathrm{TMN}\left(\mathrm{mg} \mathrm{kg}^{1}{ }^{1} \text { soil, mean }\right. \\
\text { of } 56 \text { days })\end{array}$ & $\begin{array}{l}\mathrm{TMN} \text { recovered from applied N } \\
\left(\mathrm{mg} \mathrm{kg}-{ }^{1} \text { soil }\right)\end{array}$ & $\begin{array}{l}\mathrm{N} \text { unaccounted for } \\
\left(\mathrm{mg} \mathrm{kg}^{-1} \text { soil }\right)\end{array}$ & $\begin{array}{l}\text { ANR } \\
(\%)\end{array}$ & $\begin{array}{l}\text { Increase in N recovery } \\
\text { due to NI }(\%)\end{array}$ \\
\hline $\mathrm{T}_{1}$ & 8.9 & - & - & - & - \\
$\mathrm{T}_{2}$ & 69.4 & 60 & 140 & 30 & - \\
$\mathrm{T}_{3}$ & 157.3 & 148 & 52 & 74 & 145 \\
$\mathrm{~T}_{4}$ & 118.4 & 109 & 91 & 55 & 81 \\
$\mathrm{~T}_{5}$ & 80.0 & 71 & 129 & 36 & 17 \\
\hline
\end{tabular}

$\mathrm{T}_{1}$, control; $\mathrm{T}_{2}, \mathrm{~N}$ without $\mathrm{NIs} ; \mathrm{T}_{3}, \mathrm{~N}+\mathrm{CaC}_{2} ; \mathrm{T}_{4}, \mathrm{~N}+$ karanjin; $\mathrm{T}_{5}, \mathrm{~N}+$ M. azedarach

$T M N$ total mineral nitrogen, $A N R$ apparent $\mathrm{N}$ recovery, $N I$ nitrification inhibitors

plants M. spicata, Artemisia and synthetic inhibitor, DCD, and reported that the ANR by plant material was the highest (75.1\%) with M. spicata oil followed by Artemisia oil $(62.8 \%)$, DCD (46.2\%) and urea without NIs $(35.5 \%)$.

Wheat growth, plant $\mathrm{N}$ uptake and $\mathrm{N}$-recovery

The response of growth and yield characteristics of wheat varied in response to the type of NI treatments (Table 4). Shoot length, shoot dry weight, number of leaves and root dry weight were significantly $(P \leq 0.05)$ higher in soil amended with $\mathrm{N}+M$. azedarach $\left(\mathrm{T}_{7}\right)$ compared with soil amended with $\mathrm{N}$ only $\left(\mathrm{T}_{2}\right)$. Karanjin and $\mathrm{CaC}_{2}$ did not result in any significant effect on most of the growth characteristics. Use of the $M$. azedarach extract as a nitrification inhibitor has seldom been studied. However, recently Toselli et al. (2010) reported increased productivity in peach trees after the application of $M$. azedarach fruit and leaves to the soil. The yield and yield traits were significantly higher in the soil amended with $\mathrm{CaC}_{2}$ compared with the soil amended with $\mathrm{N}$ only. In general, the number of grains spike ${ }^{-1}, 1000$-seed weight and seed yield plant ${ }^{-1}$ following NIs application increased between 39 and $52 \%, 12$ and $26 \%$, and 12 and $18 \%$, respectively, compared to $\mathrm{N}$ only. The increase in growth and yield attributes due to NIs may be attributed to better utilization of $\mathrm{N}$ by the crop as a result of decreases in $\mathrm{N}$ 
Table 4 Effect of nitrification inhibitors i.e., calcium carbide, karanjin and M. azedarach applied with $\mathrm{N}$ fertilizer on growth and yield contributing parameters of wheat (average of three repeats) grown in pots under greenhouse conditions

\begin{tabular}{lllllllll}
\hline Treatments & $\begin{array}{l}\text { Shoot } \\
\text { length }(\mathrm{cm})\end{array}$ & $\begin{array}{l}\text { Shoot dry } \\
\text { weight }(\mathrm{g})\end{array}$ & $\begin{array}{l}\text { No. of Leaves } \\
\text { plant }^{-1}\end{array}$ & $\begin{array}{l}\text { Root } \\
\text { length }(\mathrm{cm})\end{array}$ & $\begin{array}{l}\text { Root dry } \\
\text { weight }(\mathrm{g})\end{array}$ & $\begin{array}{l}\text { No. of grains } \\
\text { spike }^{-1}\end{array}$ & $\begin{array}{l}1,000 \text {-grain } \\
\text { weight }(\mathrm{g})\end{array}$ & $\begin{array}{l}\text { Grain yield } \\
\text { plant }^{-1}(\mathrm{~g})\end{array}$ \\
\hline $\mathrm{T}_{1}$ & $23.8 \mathrm{c}$ & $0.51 \mathrm{c}$ & $5.2 \mathrm{~d}$ & $7.6 \mathrm{c}$ & $0.07 \mathrm{c}$ & $11.0 \mathrm{~d}$ & $14.2 \mathrm{~d}$ & $0.28 \mathrm{e}$ \\
$\mathrm{T}_{2}$ & $53.7 \mathrm{~b}$ & $1.17 \mathrm{~b}$ & $14.3 \mathrm{bc}$ & $12.0 \mathrm{ab}$ & $0.23 \mathrm{~b}$ & $26.2 \mathrm{c}$ & $22.7 \mathrm{c}$ & $1.77 \mathrm{~d}$ \\
$\mathrm{~T}_{3}$ & $54.7 \mathrm{~b}$ & $1.23 \mathrm{~b}$ & $13.0 \mathrm{c}$ & $12.1 \mathrm{ab}$ & $0.25 \mathrm{ab}$ & $33.5 \mathrm{ab}$ & $29.5 \mathrm{a}$ & $2.28 \mathrm{a}$ \\
$\mathrm{T}_{4}$ & $56.1 \mathrm{ab}$ & $1.41 \mathrm{ab}$ & $15.8 \mathrm{ab}$ & $12.4 \mathrm{a}$ & $0.27 \mathrm{ab}$ & $32.7 \mathrm{~b}$ & $30.1 \mathrm{a}$ & $1.86 \mathrm{~cd}$ \\
$\mathrm{~T}_{5}$ & $56.1 \mathrm{ab}$ & $1.274 \mathrm{~b}$ & $15.8 \mathrm{ab}$ & $10.8 \mathrm{~b}$ & $0.24 \mathrm{ab}$ & $37.6 \mathrm{a}$ & $25.8 \mathrm{bc}$ & $2.11 \mathrm{ab}$ \\
$\mathrm{T} 6$ & $59.7 \mathrm{a}$ & $1.32 \mathrm{~b}$ & $14.0 \mathrm{bc}$ & $11.6 \mathrm{ab}$ & $0.23 \mathrm{~b}$ & $31.5 \mathrm{~b}$ & $25.4 \mathrm{bc}$ & $1.73 \mathrm{~d}$ \\
$\mathrm{~T}_{7}$ & $59.1 \mathrm{a}$ & $1.61 \mathrm{a}$ & $17.7 \mathrm{a}$ & $11.8 \mathrm{ab}$ & $0.30 \mathrm{a}$ & $32.3 \mathrm{~b}$ & $28.7 \mathrm{ab}$ & $1.99 \mathrm{bc}$ \\
$\mathrm{LSD}(P \leq 0.05)$ & 3.99 & 0.28 & 2.13 & 1.41 & 0.06 & 4.36 & 3.6 & 0.19 \\
\hline
\end{tabular}

$\mathrm{T}_{1}$, control; $\mathrm{T}_{2}, \mathrm{~N}$ without nitrification inhibitors (NIs); $\mathrm{T}_{3}, \mathrm{~N}+\mathrm{CaC}_{2}$ at the rate of $15 \mathrm{mg} \mathrm{kg}{ }^{-1} ; \mathrm{T}_{4}, \mathrm{~N}+\mathrm{CaC}_{2}$ at the rate of $30 \mathrm{mg} \mathrm{kg}^{-1} ; \mathrm{T}_{5}$, $\mathrm{N}+\mathrm{CaC}_{2}$ at the rate of $45 \mathrm{mg} \mathrm{kg}^{-1} ; \mathrm{T}_{6}, \mathrm{~N}+$ karanjin; $\mathrm{T}_{7}, \mathrm{~N}+$ M. azedarach

losses. Yaseen et al. (2006) reported that application of $\mathrm{CaC}_{2}$ with $\mathrm{N}$ fertilizer significantly increased the number of tillers (up to $45.5 \%$ ), straw (up to $32.8 \%$ ), and grain yield (up to $37.3 \%$ ) of wheat over the $\mathrm{N}$ fertilizer alone. Similarly, a $37 \%$ increase in green pod yield of Okra was observed after $\mathrm{CaC}_{2}$ application equivalent to $60 \mathrm{~kg} \mathrm{ha}^{-1}$ along with $\mathrm{N}$ fertilizer (Kashif et al. 2008). Karanjin has also been reported to increase grain and straw yield, total $\mathrm{N}$ uptake and grain protein content of rice (Sahrawat 1996).

Results indicated that $\mathrm{N}$ concentration and $\mathrm{N}$ uptake in plant shoot and grains were significantly increased in the

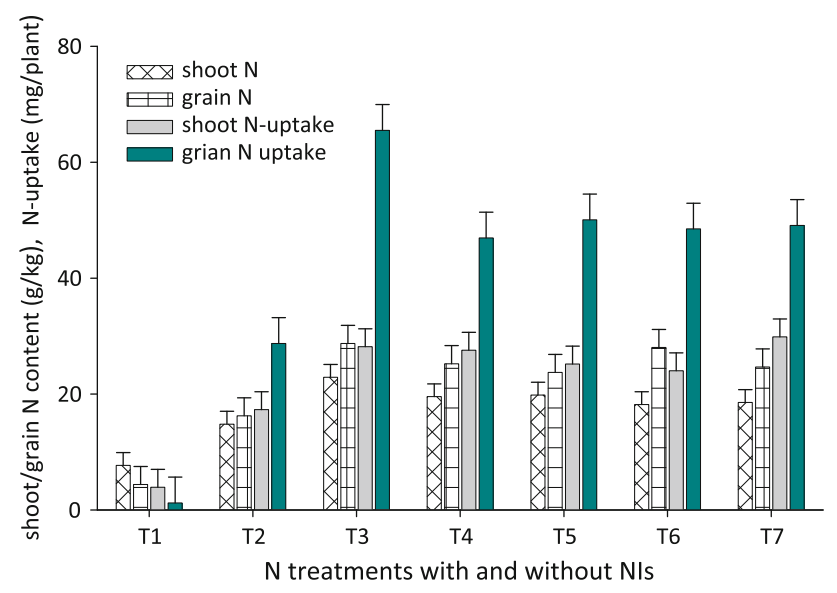

Fig. 4 Effect of nitrification inhibitors i.e., calcium carbide, karanjin and $M$. azedarach applied with $\mathrm{N}$ fertilizer on shoot and grain $\mathrm{N}$ contents and $\mathrm{N}$ uptake of wheat (average of three repeats) grown in pots under greenhouse conditions. The symbols on $X$-axis indicate: $\mathrm{T}_{1}=$ control; $\quad \mathrm{T}_{2}=\mathrm{N}$ without nitrification inhibitors (NIs); $\mathrm{T}_{3}=\mathrm{N}+\mathrm{CaC}_{2}$ at the rate of $15 \mathrm{mg} \mathrm{kg}^{-1} ; \mathrm{T}_{4}=\mathrm{N}+\mathrm{CaC}_{2}$ at the rate of $30 \mathrm{mg} \mathrm{kg}^{-1} ; \mathrm{T}_{5}=\mathrm{N}+\mathrm{CaC}_{2}$ at the rate of $45 \mathrm{mg} \mathrm{kg}^{-1}$; $\mathrm{T}_{6}=\mathrm{N}+$ karanjin; $\mathrm{T}_{7}=\mathrm{N}+$ M. azedarach treatments supplemented with NIs (Fig. 4). The relative increase in shoot and grain $\mathrm{N}$ concentration due to NIs was between 23 and $40 \%$, and 52 and $73 \%$, respectively over $\mathrm{N}$ fertilizer only. Similarly, the relative increase in shoot and grains $\mathrm{N}$ uptake due to NIs was between 41 and $76 \%$, and 66 and $87 \%$, respectively. Response of total $\mathrm{N}$ uptake to different amendments is presented in Fig. 5. The total $\mathrm{N}$ uptake in $\mathrm{N}$ fertilizer treatment was $46 \mathrm{mg} \mathrm{N}$ plant $^{-1}$ that significantly $(P \leq 0.05)$ increased to 94,75 , $74 \mathrm{mg} \mathrm{N}$ plant ${ }^{-1}$ (mean $81 \mathrm{mg} \mathrm{N}$ plant ${ }^{-1}$ ) with $\mathrm{CaC}_{2}, 73$ and $79 \mathrm{mg} \mathrm{N}$ plant $^{-1}$ with karanjin and M. azedarach, respectively. Application of $\mathrm{CaC}_{2}$ at the rate of 30 $\mathrm{mg} \mathrm{kg}^{-1}$ soil exhibited the highest $\mathrm{N}$ uptake of $94 \mathrm{mg} \mathrm{N}$ plant $^{-1}$.

The $\mathrm{N}$ concentration in shoots and grains of wheat was significantly increased with NIs compared to $\mathrm{N}$ application alone (Fig. 4). The relative increase in shoot and grain $\mathrm{N}$ concentration due to NIs was between 23 and $40 \%$, and 52 and $73 \%$, respectively over $\mathrm{N}$ fertilizer without NIs. Among the three NIs tested, $\mathrm{CaC}_{2}$ showed the highest response. Application of lower rate of $\mathrm{CaC}_{2}$ i.e., $15 \mathrm{mg} \mathrm{kg}^{-1}$ showed significantly higher $\mathrm{N}$ concentration both in shoot and grains of wheat.

Results indicated that $\mathrm{N}$ uptake in plant shoot and grains was significantly increased in the treatments supplemented with NIs (Fig. 4). The relative increase in shoot and grains $\mathrm{N}$ uptake due to NIs was between 41 and $76 \%$, and 66 and $87 \%$, respectively over the $\mathrm{N}$ treatment without NIs. Similarly, response of total $\mathrm{N}$ uptake to different amendments is presented in Fig. 5. The total $\mathrm{N}$ uptake in $\mathrm{N}$ fertilizer treatment was $46 \mathrm{mg} \mathrm{N}$ plant $^{-1}$ that significantly $(P \leq 0.05)$ increased to $94,75,74 \mathrm{mg} \mathrm{N}$ plant $^{-1}$ (mean $81 \mathrm{mg} \mathrm{N}$ plant ${ }^{-1}$ ) with $\mathrm{CaC}_{2}, 73$ and $79 \mathrm{mg} \mathrm{N}$ plant $^{-1}$ with karanjin and $M$. azedarach, respectively. The relative increase in $\mathrm{N}$ uptake due to $\mathrm{CaC}_{2}$, karanjin, and 
Fig. 5 Effect of nitrification inhibitors i.e., calcium carbide, karanjin and $M$. azedarach applied with $\mathrm{N}$ fertilizer on total $\mathrm{N}$ uptake and apparent $\mathrm{N}$ recovery by wheat grown in pots under greenhouse conditions. The symbols on $X$-axis indicate: $\mathrm{T}_{1}=$ control; $\mathrm{T}_{2}=\mathrm{N}$ without nitrification inhibitors (NIs);

$\mathrm{T}_{3}=\mathrm{N}+\mathrm{CaC}_{2}$ at the rate of $15 \mathrm{mg} \mathrm{kg}^{-1} ; \mathrm{T}_{4}=\mathrm{N}+\mathrm{CaC}_{2}$ at the rate of $30 \mathrm{mg} \mathrm{kg}^{-1}$;

$\mathrm{T}_{5}=\mathrm{N}+\mathrm{CaC}_{2}$ at the rate of $45 \mathrm{mg} \mathrm{kg}^{-1}$;

$\mathrm{T}_{6}=\mathrm{N}+$ karanjin;

$\mathrm{T}_{7}=\mathrm{N}+$ M. azedarach
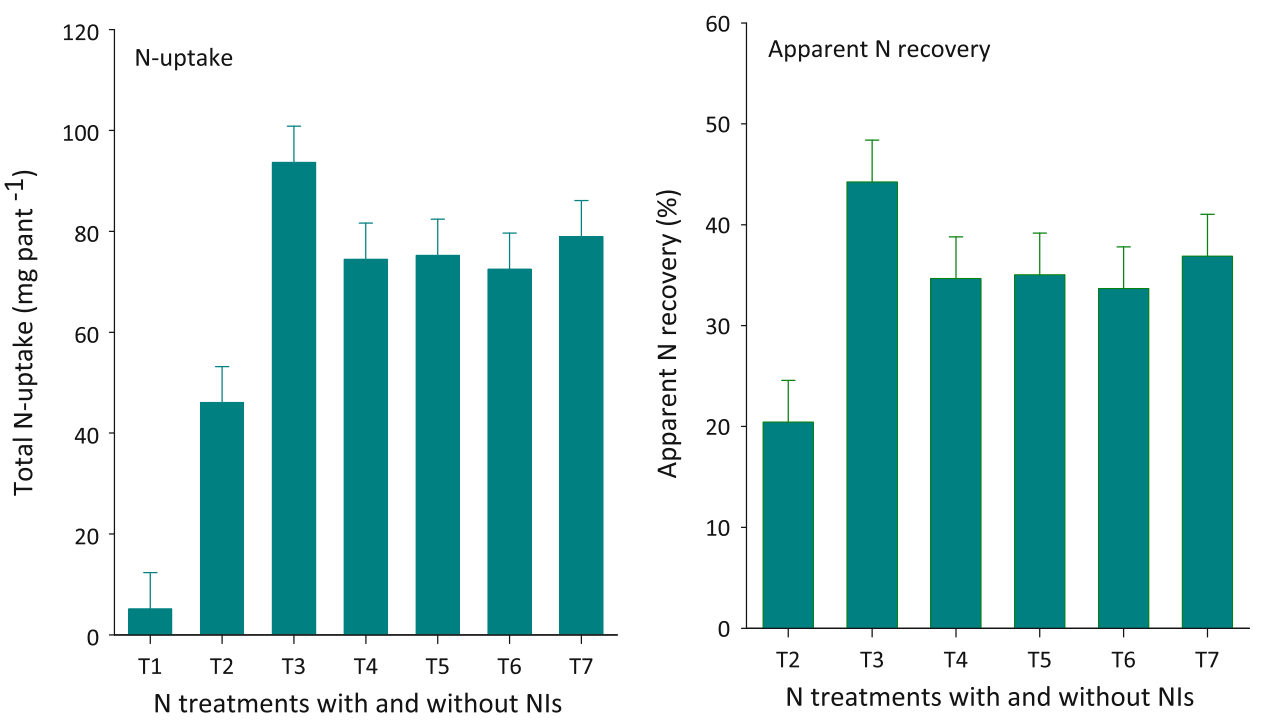

M. azedarach over $\mathrm{N}$ fertilizer was 76,59 , and $72 \%$, respectively. Application of $\mathrm{CaC}_{2}$ at the rate of $30 \mathrm{mg} \mathrm{kg}^{-1}$ soil exhibited the highest $\mathrm{N}$ uptake of $94 \mathrm{mg} \mathrm{N}_{\text {plant }}{ }^{-1}$.

Mahmood et al. (2007) reported a 14 and $24 \%$ increase in total $\mathrm{N}$ uptake (over the $\mathrm{N}$ only treatment) in wheat due to the application of 30 and $45 \mathrm{mg} \mathrm{kg}^{-1} \mathrm{CaC}_{2}$, respectively. Freney et al. (1992) reported that $\mathrm{CaC}_{2}$ when applied with $\mathrm{N}$ fertilizer limited $\mathrm{NH}_{4}{ }^{+}$oxidation and prevented $\mathrm{N}$ loss thereby increasing accumulation of $\mathrm{N}$ both in shoot and grains of wheat. Application of M. azedarach to Peach increased shoot $\mathrm{N}$ concentration by 24 and $33 \%$ over $\mathrm{N}$ treatment applied alone (Toselli et al. 2010).

Results indicated that the plants supplemented with $\mathrm{N}+$ NIs recovered more $\mathrm{N}$ than those which received $\mathrm{N}$ only (Fig. 5). The apparent $\mathrm{N}$ recovery (ANR) of $\mathrm{N}$ amended plants was $20 \%$ which was significantly increased to $44,35,35 \%$ (mean $38 \%$ ) with $\mathrm{CaC}_{2}, 34$ and $37 \%$ with karanjin and $M$. azedarach, respectively. The increase in the recovery of applied N due to NIs may be due to the inhibition of nitrification (less chance of $\mathrm{N}$ losses) thereby retaining $\mathrm{NH}_{4}^{+}-\mathrm{N}$ in mineral pool that may be utilized by the plants for longer period. Our results are in agreement with the previous findings (Freney et al. 1992; Kiran and Patra 2003; Mahmood et al. 2007). Yaseen et al. (2006) reported that application of encapsulated $\mathrm{CaC}_{2}$ resulted in greater $\mathrm{N}$ use efficiency (NUE) (up to $61.1 \%$ ) by both wheat and cotton crops than that observed with the same rates of $\mathrm{N}$ fertilizer alone.

\section{Conclusion}

The present study exhibited higher rate of $\mathrm{NH}_{4}^{+}-\mathrm{N}$ disappearance from the mineral $\mathrm{N}$ pool over a short period of time under moisture and temperature conditions (temperature $22{ }^{\circ} \mathrm{C} ; 58 \%$ WFPS) which normally exist in the field during kharif (summer) season. These findings suggested that $\mathrm{N}$ use efficiency and $\mathrm{N}$ recovery is critical in soil-plant systems because of the possible losses and $\mathrm{N}$ disappearance from the system. The applied $\mathrm{N}$ in this study was nitrified rapidly with $70 \%$ of the total mineral $\mathrm{N}$ converted to $\mathrm{NO}_{3}{ }^{-}-\mathrm{N}$ within 56 days of incubation. This accumulated $\mathrm{NO}_{3}{ }^{-}$is real concern for the environment, $\mathrm{N}$ recovery and crop productivity. Results of this study demonstrated that NIs calcium carbide, karanjin and M. azedarach when applied with $\mathrm{N}$ fertilizer DAP, significantly reduced $\mathrm{NO}_{3}{ }^{-}$accumulation and maintained $\mathrm{NH}_{4}{ }^{+}$in the mineral pool at higher concentration and for a longer period. By delaying and decreasing the extent of $\mathrm{NH}_{4}{ }^{+}$oxidation, NIs were able to increase $\mathrm{N}$ recovery in soil-plant systems possibly because of reducing $\mathrm{N}$ losses associated with nitrification. Calcium carbide and karanjin were found effective in reducing $\mathrm{NO}_{3}{ }^{-}$accumulation and increasing $\mathrm{N}$ recovery in soil while $M$. azedarach was equally effective in plant growth promoting ability. On the basis of these results, it is imperative to exploit and introduce NIs especially those which are efficient, cost-effective, and suitable for both tropical and temperate production systems. Since this study was conducted in the laboratory scale, the benefits found here need to be further investigated in field scale experiments to assess the $\mathrm{N}$ use efficiency and $\mathrm{N}$ balances of these NIs in soil-crop systems.

Acknowledgments We are grateful to our colleague Mr. Hamid of the Department of Eastern Medicine and Surgery, The University of Poonch, Rawalakot Azad Jammu and Kashmir for providing Karanjin for this experiment. The work reported here was financially supported by the University of Azad Jammu and Kashmir through the grant "Promotion of Research." 


\section{References}

Abbasi MK, Adams WA (1998) Loss of nitrogen in compacted grassland soil by simultaneous nitrification and denitrification. Plant Soil 200:265-277

Abbasi MK, Adams WA (2000a) Gaseous N emission during simultaneous nitrification-denitrification associated with mineral $\mathrm{N}$ fertilization to a grassland soil under field conditions. Soil Biol Biochem 32:1251-1259

Abbasi MK, Adams WA (2000b) Estimation of simultaneous nitrification and denitrification in grassland soil associated with urea-N using ${ }^{15} \mathrm{~N}$ and nitrification inhibitor. Biol Fertil Soils 31:38-44

Abbasi MK, Khizar A (2012) Microbial biomass carbon and nitrogen transformations in a loam soil amended with organic-inorganic $\mathrm{N}$ sources and their effect on growth and $\mathrm{N}$-uptake in maize. Ecol Eng 123:132-139

Abbasi MK, Shah Z, Adams WA (2003) Effect of the nitrification inhibitor nitrapyrin on the fate of nitrogen applied to a soil incubated under laboratory condition. J Plant Nutr Soil Sci $166: 513-518$

Abbasi MK, Hina M, Tahir MM (2011) Effect of Azadirachta indica (neem), sodium thiosulphate and calcium chloride on changes in nitrogen transformations and inhibition of nitrification in soil incubated under laboratory conditions. Chemosphere 82:1629-1635

Dinnes DL, Karlen DL, Jaynes DB, Kaspar TC, Hatfield JL, Colvin TS, Cambardella CA (2002) Nitrogen management strategies to reduce nitrate leaching in tile drained midwestern soils. Agron J 94:153-171

Fangueiro D, Fernandes A, Coutinho J, Moreira N, Trindade H (2009) Influence of two nitrification inhibitors (DCD and DMPP) on annual ryegrass yield and soil mineral $\mathrm{N}$ dynamics after incorporation with Cattle Slurry. Commun Soil Sci Plant Anal 40:3387-3398

Freney JR, Smith CJ, Mosier AR (1992) Effect of a new nitrification inhibitor (wax coated calcium carbide) on transformations and recovery of fertilizer nitrogen by irrigated wheat. Fert Res 32:1-12

Freney JR, Chen DL, Mosier AR, Rochester IJ, Constable GA, Chalk PM (1993) Use of nitrification inhibitors to increase fertilizer nitrogen recovery and lint yield in irrigated cotton. Fert Res 34:37-44

Freney JR, Randall PJ, Smith JWB, Hodgkin J, Harrington KJ, Morton TC (2000) Slow release sources of acetylene to inhibit nitrification in soil. Nutr Cycl Agroecosyst 56:241-251

Glass ADM (2003) Nitrogen use efficiency of crop plants: physiological constraints upon nitrogen absorption. Crit Rev Plant Sci $22: 453-470$

IFA (2012) International Fertilizer Association-Statistics. www. fertilizer.org/HomePage/STATISTICS

Jackson ML (1962) Soil chemical analysis. Prentice-Hall Inc., Englewood Cliffs

Kashif SR, Yaseen M, Arshad M, Ayub M (2008) Response of okra (Hibiscus esculentus L.) to soil given encapsulated calcium carbide. Pak J Bot 40:175-181

Keeney, Nelson DW (1982) Nitrogen-inorganic forms. In: Page AL, Miller RH, Keeney (eds) Methods of soil analysis, chemical and microbiological properties, part 2. SSSA, Madison, pp 643-693

Keerthisinghe DG, Freney JR, Mosier AR (1993) Effect of waxcoated calcium carbide and nitrapyrin on nitrogen loss and methane emission from dry-seeded flooded rice. Biol Fertil Soils 16:71-75

Keerthisinghe DG, Xin-Jian L, Qi-Xiang L, Mosier AR (1996) Effect of encapsulated calcium carbide and urea application methods on denitrification and $\mathrm{N}$ loss from flooded rice. Fert Res 45:31-36
Khalil MI, Gutser R, Schmidhalter U (2009) Effects of urease and nitrification inhibitors added to urea on nitrous oxide emissions from a loess soil. J Plant Nutr Soil Sci 172:651-660

Kiran U, Patra DD (2003) Medicinal and aromatic plant materials as nitrification inhibitors for augmenting yield and nitrogen uptake of Japanese mint (Mentha arvensis L. Var. Piperascens). Bioresour Technol 86:267-276

Mahmood R, Yaseen M, Arshad M (2007) Effect of rate and time of calcium carbide application on nitrogen use efficiency of applied urea and growth of wheat. Pak J Bot 39:497-502

Majumdar D (2002) Suppression of nitrification and $\mathrm{N}_{2} \mathrm{O}$ emission by karanjin-a nitrification inhibitor prepared from karanja (Pongamia glabra Vent.). Chemosphere 47:845-850

Majumdar D, Dutta A, Kumar S, Pathak H, Jain MC (2001) Mitigation of $\mathrm{N}_{2} \mathrm{O}$ emission from an alluvial soil by application of karanjin. Biol Fertil Soils 33:438-442

Majumdar D, Pandya B, Arora A, Dhara A (2004) Potential use of karanjin (3-methoxy furano-2', 3', 7, 8-flavone) as a nitrification inhibitor in different soil types. Arch Agron Soil Sci 50:455-465

Marino G, Toselli M, Baldi E, Marangoni B (2009) Effect of soilapplied ground leaves of Melia azaderach $\mathrm{L}$. on acclimatization of bacteria-contaminated rooted plum shoot. Acta Hort 812: $447-453$

McCarty GW (1999) Mode of action of nitrification inhibitors. Biol Fertil Soils 29:1-9

Patra DD, Sukhma C (2009) Natural nitrification inhibitors for augmenting nitrogen use efficiency in soil-plant system. The Proceedings of the International Plant Nutrition Colloquium XVI, UC Davis. http://escholarship.org/uc/item/4h30z8tg

Pereira J, Fangueiro D, Chadwick DR, Misselbrook TH, Coutinho J, Trindade H (2010) Effect of cattle slurry pre-treatment by separation and addition of nitrification inhibitors on gaseous emissions and $\mathrm{N}$ dynamics: a laboratory study. Chemosphere 79:620-627

Prasad R, Power JF (1995) Nitrification inhibitors for agriculture, health, and the environment. Adv Agron 54:233-281

Raun WR, Johnson GV (1999) Improving nitrogen use efficiency for cereal production. Agron J 91:357-363

Remde A, Conrad R (1991) Role of nitrification and denitrification for NO metabolism in soil. Biogeochem 12:189-205

Rodgers GA (1986) Nitrification inhibitors in agriculture. J Environ Sci Health A 21:701-722

Sahrawat KL (1996) Nitrification inhibitors, with emphasis on natural products, and the persistence of fertilizer nitrogen in soil. In: Ahmed N (ed) Nitrogen economy in tropical soils. Kluwer, Dordrecht, pp 379-388

Smith C, Freney J, Mosier AR (1993) Effect of acetylene provided by wax-coated calcium carbide on transformations of urea nitrogen applied to an irrigated wheat crop. Biol Fertil Soils 16:86-92

Souri MK (2008) Characterisation of natural and synthetic nitrification inhibitors and their potential use in tomato cultivation. Ph.D. Dissertation, Institute of Plant Nutrition, Faculty of Agricultural Sciences, the University of Hohenheim, Germany

Souri MK (2010) Effectiveness of chloride compared to 3, 4-dimethylpyrazole phosphate on nitrification inhibition in soil. Commun Soil Sci Plant Anal 41(14):1769-1778

StatGraphics Manugistics (1992) Statistical graphics system by statistical graphics corporation, reference manual, vol 6. Manugistics, Rockville

Subbarao GV, Ishikawa T, Ito O, Nakahara K, Wang HY, Berry WL (2006a) A bioluminescence assay to detect nitrification inhibitors released from plant roots: a case study with Brachiaria humidicola. Plant Soil 288:101-112 
Subbarao GV, Ito O, Sahrawat KL, Berry WL, Nakahara K, Ishikawa T, Watanabe T, Suenaga K, Rondon M, Rao IM (2006b) Scope and strategies for regulation of nitrification in agricultural systems-challenges and opportunities. Crit Rev Plant Sci 25:303-335

Toselli M, Baldi E, Sorrenti G, Quartieri M, Marangoni B (2010) Evaluation of the effectiveness of soil-applied plant derivatives of Meliaceae species on nitrogen availability to peach trees. Sci Hort 124:183-188

Upadhyay RK, Patra DD, Tewaris SK (2011) Natural nitrification inhibitors for higher nitrogen use efficiency, crop yield, and for curtailing global warming. J Trop Agric 49:19-24
Warneke S, Schipper LA, Bruesewitz DA, McDonald I, Cameron S (2011) Rates, controls and potential adverse effects of nitrate removal in a denitrification bed. Ecol Eng 37:511-522

Yaseen M, Arshad M, Khalid A (2006) Effect of acetylene and ethylene gases released from encapsulated calcium carbide on growth and yield of wheat and cotton. Pedobiologia 50:405-411

Zaman M, Saggar S, Blennerhassett JD, Singh J (2009) Effect of urease and nitrification inhibitors on $\mathrm{N}$ transformation, gaseous emissions of ammonia and nitrous oxide, pasture yield and $\mathrm{N}$ uptake in grazed pasture system. Soil Biol Biochem 41:1270-1280 